\title{
In vitro toxicological assessment of Arrabidaea brachypoda (DC.) Bureau: Mutagenicity and estrogenicity studies
}

\author{
Flávia Aparecida Resende ${ }^{a}{ }^{*}$, Catarine Haidê Nogueira ${ }^{b}$, Lívia Greghi Espanha ${ }^{b}$, \\ Paula Karina Boldrin ${ }^{\text {b }}$, Ana Paula Oliveira-Höhne ${ }^{\text {b }}$, Mariana Santoro de Camargo a, c, \\ Cláudia Quintino da Rocha ${ }^{\mathrm{d}}$, Wagner Vilegas ${ }^{\mathrm{e}}$, Eliana Aparecida Varanda ${ }^{\mathrm{b}}$ \\ a UNIARA- University of Araraquara, Department of Biological Sciences and Health, CEP 14801-340, Araraquara, São Paulo, Brazil \\ ${ }^{\mathrm{b}}$ UNESP-São Paulo State University, Faculty of Pharmaceutical Sciences of Araraquara, Department of Biological Sciences, CEP 14801-902, Araraquara, São \\ Paulo, Brazil \\ ${ }^{c}$ UFSCAR- Federal University of São Carlos, Centro de Ciências Exatas e de Tecnologia (CCET), CEP 13565-905, São Carlos, Brazil \\ d UFMA-Federal University of Maranhão, Centro de Ciências Exatas e de Tecnologia (CCET), Department of Chemistry, CEP 65065-545, São Luis, Brazil \\ e UNESP-São Paulo State University, Experimental Campus of the Paulista Coast, CEP 11330-900, São Vicente, São Paulo, Brazil
}

\section{A R T I C L E I N F O}

\section{Article history:}

Received 27 April 2017

Accepted 14 August 2017

Available online 18 August 2017

\section{Keywords:}

Arrabidaea brachypoda

Ames test

Recombinant yeast assay (RYA)

Medicinal plants

\begin{abstract}
A B S T R A C T
Arrabidaea brachypoda (DC.) Bureau is a shrub native Cerrado, known as "cipó-una", "tintureiro" or "cervejinha do campo" and popularly used in Southeastern and Northeastern Brazil to treatment of kidney stones and painful joints (arthritis). Nevertheless, scientific information regarding this species is scarce, and there are no reports related to its possible estrogenic and mutagenic effects. Thus, the principal objective of this study was to assess the mutagenic and estrogenic activities of the hydroalcoholic extracts of the leaves, stalks, roots, their respective fractions and isolated compounds of A. brachypoda. The mutagenic activity was evaluated by the Ames test on Salmonella typhimurium strains TA98, TA97a, TA100 and TA102, in the absence (-S9) and presence (+S9) of metabolic activation system. In the RYA was used Saccharomyces cerevisiae engineered strain BY4741 (MATaura3 $\Delta 0$ leu2 $\Delta 0$ his $3 \Delta 1$ met15 0 ) which reproduce the natural pathway of genetic control by estrogens in vertebrate cells; it has the advantage of its simplicity and a high throughput. All extracts and aqueous fraction of leaves A. brachypoda were mutagenic. The crude extract is more active than the fraction, suggesting a synergic effect. Only hydroalcoholic extracts of leaves and roots of A. brachypoda showed significant estrogenic activity, with ER $\alpha$-dependent transcriptional activation activity. The obtained results in this study showed the presence of compounds capable of interacting with the estrogen receptor and to induce damage in the genetic material. Thus, we demonstrated the risk which the population is subjected due to indiscriminate use of extracts without detailed study.
\end{abstract}

(C) 2017 Elsevier Inc. All rights reserved.

\section{Introduction}

In Brazil, the estimated number of described plant species (terrestrial and algae) ranges from 50,542 to 60,042, distributed in six different biomes: Amazônia, Cerrado, Mata Atlântica, Caatinga, Pampa and Pantanal. Thus, the great biodiversity is a highlight of Brazilian flora. However, the therapeutic potentialities of most species used in folk medicine remain unknown (Silva et al., 2016).

The genus Arrabidaea, belonging to the tribe Bignonieae, contains approximately 70 species that occur from Mexico to

\footnotetext{
* Corresponding author.

E-mail address: flaviabiomed@yahoo.com.br (F.A. Resende).
}

Argentina. Among the species, Arrabidaea brachypoda (DC.) Bureau is a shrub native Cerrado, known as "cipó-una", "tintureiro" or "cervejinha do campo" and popularly used in Southeastern and Northeastern Brazil to treatment of kidney stones and painful joints (arthritis). Studies show antifungal (Alcerito et al., 2002), antiviral (Brandão et al., 2010), anti-inflammatory and antinocicepitive effects in animal models (Rocha et al., 2011), a promising action in vitro and in vivo anti-Trypanosoma cruzi (Rocha et al., 2014) and more recently in vivo gastroprotective effects (Rocha et al., 2017).

With respect to other species, several activities are attributed to the genus Arrabidaea, including anti-T. cruzi action on A. triplinervia (Leite et al., 2006), antifungal in A. bilabiata (González et al., 2000), antioxidant in A. samydoides (Pauletti et al., 2003), antimicrobial 
activity in $A$. harleyi (Lima et al., 2003), among others.

The species $A$. chica, an important folk medicine plant native to the Amazon region, has been the most studied and used to treat anemia, hemorrhage, inflammation, intestinal colic, hepatitis, and skin affections (Santos et al., 2013). According to the literature, pharmacological studies have demonstrated cytotoxic and leishmanicidal potential (Cortez de Sá et al., 2016), anti-T. cruzi (Barbosa et al., 2008), anti-inflammatory, antiangiogenic and antiproliferative activities (Michel et al., 2015), antimicrobial activity (Mafioleti et al., 2013) and significant antioxidant activity (Siraichi et al., 2013). Previous phytochemical studies of this plant have shown the presence of tannins, flavonoids (7,4'-dihydroxy-5methoxyflavone, luteolin, carajuruflavone, apigenin, escutelarina and isoescutelarina), phytosterols, anthocyanidins and pigments used in cosmetics like carajurone and carajurin (Zorn et al., 2001; Barbosa et al., 2008; Gemelli et al., 2015).

Given that natural products are promising sources of novel potentially therapeutic agents, the wide use of the genus Arrabidaea in the folk medicine and the advances of phytochemical studies of the species $A$. brachypoda with unique phenolic compounds, the aim of the present study was to determine mutagenic potential by the Ames test and the estrogenicity by Recombinant Yeast Assay (RYA) of the standardized hydroalcoholic extracts of the leaves, stalks, roots of $A$. brachypoda, their respective aqueous and dichloromethane fractions and isolated compounds brachydin A, brachydin B and brachydin C (Fig. 1), due their great phytotherapeutic potential. The Biota/Fapesp research program for the sustainable use of Brazilian biodiversity (www.biota.org.br) includes the toxicology search of new lead compounds for treating chronic disease within its research program.

\section{Material and methods}

\subsection{Plant material}

The leaves, stalks and roots of $A$. brachypoda were collected in April 2012 at San't Ana da Serra farm João Pinheiro, Minas Gerais, Brazil. The plant was identified at the ICEB of the José Badine Herbarium of the Federal University of Ouro Preto by Prof Maria Cristina Teixeira Braga Messias. A voucher specimen ( $\left.n^{\circ} 17,935\right)$ has been deposited at the Herbarium of the Federal University of Ouro Preto, Brazil. After complete drying, the leaves, stalks and roots were separately triturated in a knife mill, and weighed yielding $790.34 \mathrm{~g}, 598.45 \mathrm{~g}$ and $498.78 \mathrm{~g}$, respectively.

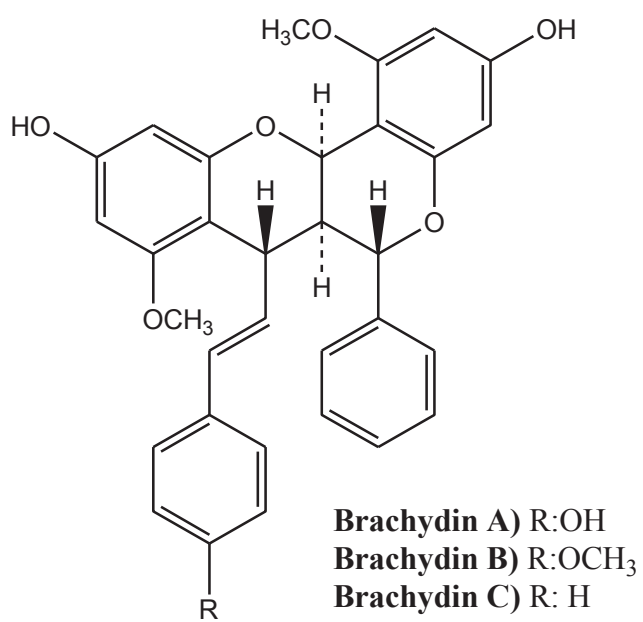

Fig. 1. Chemical structures of the isolated compounds from A. brachypoda.

\subsection{Extraction and isolation}

The dried material was extracted successively by percolation, at room temperature, with EtOH- $\mathrm{H}_{2} \mathrm{O} 70 \%$. The crude hydroalcoholic extracts were obtained after filtration and evaporated to dryness under vacuum at approximately $40{ }^{\circ} \mathrm{C}$, yielding $13.0 \mathrm{~g}$ of an aqueous-ethanol extract of leaves, $9.0 \mathrm{~g}$ of stalk and $11.0 \mathrm{~g}$ of root. Further liquid/liquid extractions with the hydroalcoholic extract from roots were carried out using $\mathrm{CH}_{2} \mathrm{Cl}_{2}(1 \mathrm{~L})$ and $\mathrm{H}_{2} \mathrm{O}-\mathrm{MeOH}(7: 3)$ (1 L). The crude $\mathrm{CH}_{2} \mathrm{Cl}_{2}$ and hydro-methanolic fractions were obtained after decantation and evaporated to dryness under vacuum at approximately $40{ }^{\circ} \mathrm{C}$, yielding $35.2 \%$ (3.87 g) and 64.8\% (5.13 g) of the dried fractions, respectively, based on the dry mass. The dichloromethane extract-DCM $(2.5 \mathrm{~g})$ was fractionated initially using preparative HPLC with a Luna ${ }^{\circledR} \mathrm{C} 18$ column as the stationary phase $18(5 \mu \mathrm{m}, 150 \times 49 \mathrm{~mm}$ i.d.); $\mathrm{MeOH}$ and $0.002 \%$ formic acid in water were added using a linear gradient from $5 \%$ to $100 \% \mathrm{MeOH}$ over 60 min period. The flow rate was $10 \mathrm{~mL} \mathrm{~min}^{-1}$, and the UV absorbance was detected at $217 \mathrm{~nm}$ This procedure was repeated seven times. The HPLC generated 5 fractions. Each fraction was analyzed by HPLC-PDA. Fractions 1 ( $85 \mathrm{mg}$ ), fractions 3 (70,2 $\mathrm{mg})$, and fractions 5 (103.2 mg), yielded compounds brachydin A (1), brachydin $B(2)$ and brachydin C (3), respectively. The isolation and structure elucidation of the compounds were described by Rocha et al. (2014).

\subsection{Ames test}

The mutagenicity was tested by the Salmonella/microsome assay (Ames test), by pre-incubation method, with (+S9) and absence (-S9) metabolic activation (Maron and Ames, 1983). The test strains of Salmonella typhimurium TA98, TA100, TA102 and TA97a were kindly provided by Dr. Ames BN (Berkeley, CA, USA). These strains were cultured overnight from frozen cultures for $12-14 \mathrm{~h}$ in Oxoid Nutrient Broth No. 2. S9 mix was used for the evaluation of indirectacting mutagens. The mixture of metabolic activation (S9 mix) prepared from liver of Sprague-Dawley rats treated with the mixture Aroclor 1254 polychlorinated biphenyl (500 mg/kg) was purchased from Molecular Toxicology Inc. through (Boone, NC USA) and freshly prepared before each test. Metabolic activation system consisted of $4 \%$ of $\mathrm{S} 9,1 \% 0.4 \mathrm{M} \mathrm{MgCl}_{2}, 1 \% \mathrm{KCl} 1.65 \mathrm{M}, 0.5 \%$ of disodium D-glucose-6-phosphate 1M, 4\% 0.1M NADP, 50\% 0.2M phosphate buffer and 39.5\% sterile distilled water (Maron and Ames, 1983).

For the determination of the mutagenic activity, different concentrations of crude extracts of the leaves, stalks and roots, and their aqueous and dichloromethane fractions diluted in dimethylsulfoxid (DMSO) were assayed. The sample concentrations were selected based on a preliminary test for toxicity. In all subsequent assays, the upper limit of the dosage range tested was the highest non-toxic dose and the toxic dose lowest determined in this preliminary assay. The toxicity was detected either as a reduction in the number of revertant histidine (His+) or a decrease in the growth thickness of the bottom (background lawn).

The various concentrations of samples to be tested were added $0.5 \mathrm{~mL}$ of $0.2 \mathrm{M}$ phosphate buffer or $0.5 \mathrm{~mL}$ of $4 \% \mathrm{~S} 9 \mathrm{mix} ; 0.1 \mathrm{~mL}$ of bacterial culture and then incubated at $37^{\circ} \mathrm{C}$ for $20-30 \mathrm{~min}$. Then, $2 \mathrm{~mL}$ of top agar was added and the mixture was poured into plates containing agar minimal.

The plates were incubated at $37{ }^{\circ} \mathrm{C}$ for $48 \mathrm{~h}$, and colonies His+ revertants were counted manually. All experiments were performed in triplicate. The standard mutagens used as positive controls in experiments without S9 mix were 4-nitro-o-phenylenediamine (10 $\mu \mathrm{g} /$ plate for TA98 and TA97a), sodium azide (1.25 $\mu \mathrm{g} /$ plate for TA100) and mitomycin C $(0.5 \mu \mathrm{g} /$ plate for TA102). In 
experiments with metabolic activation, 2-anthramine $(1.25 \mu \mathrm{g} /$ plate for TA98, TA100 and TA97a) and 2-aminofluorene $(10.0 \mu \mathrm{g} /$ plate for TA102) were used. DMSO (100 or $75 \mu \mathrm{L} /$ plate) served as negative control (solvent).

The results were analyzed with the statistical software package Salanal 1.0 (U.S. Environmental Protection Agency, Monitoring Systems Laboratory, Las Vegas, NV, from Research Triangle Institute, RTP, NC, USA), adopting the Bernstein et al. (1982) model. The data (revertants/plate) were assessed by analysis of variance (ANOVA), followed by linear regression. The mutagenic index (MI) was also calculated for each concentration tested, this being the average number of revertants per plate with the test sample divided by the average number of revertants per plate with the negative (solvent) control. A sample was considered mutagenic when a dose-response relationship was detected and a two-fold increase in the number of mutants ( $\mathrm{MI} \geq 2$ ) was observed for at least one concentration (Resende et al., 2012).

\subsection{Recombinant yeast assay (RYA)}

The RYA tests were performed essentially as in Garcia-Reyero et al. (2001). Briefly, yeast strain BY4741 (MATa ura3 $\Delta 0$ leu2 $\Delta 0$ his $3 \Delta 1$ met15 $\Delta 0$ ) (EUROSCARF, Frankfurt, Germany), which was kindly provided by Dr Benjamin Pinã (CSIC, Barcelona, Spain), was transformed with plasmids pH5HE0 and pVitBX2 (Garcia-Reyero et al., 2001).

Expression plasmid pH5HE0 contains the human estrogen hormone receptor gene HEO (Green and Chambon, 1991), cloned into the constitutive yeast expression vector pAAH5 (Schneider and Guarente, 1991). The reporter plasmid pVITB2x contains two copies of the pseudo-palindromic estrogen responsive element from the Xenopus laevis vitellogenin B1 gene (5'-AGTCACTGTGACC39 ) inserted into the unique KpnI site of pSFLD-178K (Garcia-Reyero et al., 2004).

Transformed clones were first grown in $3 \mathrm{~mL}$ of rich complete medium at $30{ }^{\circ} \mathrm{C}$. Next, they were grown overnight in minimal medium. The final culture was adjusted to an optical density (OD) of 0.1 at $600 \mathrm{~nm}$ and distributed in the wells of a siliconized 96well polypropylene microliter plate (NUNCTM, U96 PP $0.5 \mathrm{~mL}$ ), at $90 \mu \mathrm{L}$ in the first row. Aliquots of $10 \mu \mathrm{L}$ of the samples, at initial concentration of $1.5 \mathrm{mg} / \mathrm{mL}$ for hydroalcoholic extracts of leaves and roots of A. brachypoda, $75 \mathrm{mg} / \mathrm{mL}$ for hydroalcoholic extract of stalks and aqueous and dichloromethane fractions of roots, $7.5 \mathrm{mg} /$ $\mathrm{mL}$ for aqueous and dichloromethane fractions of leaves and stalks and $4 \mathrm{mg} / \mathrm{mL}$ for isolated substances, brachydin A, brachydin B and brachydin $C$, were dispensed into wells on the first row and serial dilutions were prepared along the plate, containing samples with dilution factors $1: 10,1: 30,1: 90,1: 270$ and 1:810. All the used concentrations are determinate in previous experiments of toxicity.

A positive control was made by adding $17-\beta$-estradiol at a final concentration of $10 \mathrm{nM}$. Moreover, we included a toxicity control, by adding $10 \mathrm{nM}$ of $17-\beta$-estradiol to a sample with a dilution factor of $1: 30$, and $10 \%$ DMSO as the negative control.

Plates were incubated for $6 \mathrm{~h}$ at $30^{\circ} \mathrm{C}$ under mild shaking. After incubation, $50 \mu \mathrm{L}$ of Y-PERTM (PIERCETM, Rockford, IL, USA) was added to each well and incubated at $30{ }^{\circ} \mathrm{C}$ for a further $30 \mathrm{~min}$. Afterwards, $50 \mu \mathrm{L}$ of assay buffer was added to the lysed cells. The assay buffer was prepared by mixing $100 \mathrm{~mL}$ Z-buffer, $1 \mathrm{~mL}$ Triton X-100 (Sigma), 1 mL SDS 10\%, $70 \mu \mathrm{L}$ 2-mercaptoethanol (Fluka) and $21 \mathrm{mg}$ of 4-methylumbelliferyl $\beta$-D-galactoside (Sigma). Z-Buffer is a mix of: $60 \mathrm{mM} \mathrm{Na} \mathrm{HPO}_{4}, 40 \mathrm{mM} \mathrm{NaH}_{2} \mathrm{PO}_{4}, 10 \mathrm{mM} \mathrm{KCl}$ and $1 \mathrm{mM}$ $\mathrm{MgSO}_{4}, \mathrm{pH}$ 7.0.

After centrifugation, plates were read in a spectrofluorometer (Synergy H1, Biotek), at $355 \mathrm{~nm}$ excitation and $460 \mathrm{~nm}$ emission wavelengths. Fluorescence was recorded for $20 \mathrm{~min}$ (one measurement per min); $\beta$-galactosidase activity was calculated as the rate of increase of fluorescence (in arbitrary units). Data analysis of fluorescence units was performed with GraphPad Prism 5.0 (GraphPad Software Inc. San Diego, CA), using the ANOVA test followed by the Tukey test $(\mathrm{p}<0.05)$. RYA does not provide a direct measurement of the molar (or mass) concentration of endocrine disruptors, but of their estrogenic activity. For simplification, results were calculated as estradiol equivalents (EEQ), defined as the amount of estradiol that should be present to account for the observed response in a given sample. These equivalents were calculated from the lowest dilution in which the $\beta$-galactosidase activity was indistinguishable from that of the control (only vehicle).

To translate results from serial dilutions to EEQ we assumed that hormonal dose-response curves follow a sigmoidal function:

$$
\frac{\mathrm{R}-\mathrm{R} 0}{\mathrm{Rmax}-\mathrm{R} 0}=\frac{1}{1+\frac{\mathrm{Kd}}{[\mathrm{L}]}}
$$

in which $\mathrm{R} 0, \mathrm{R}$, and Rmax represent $\beta$-galactosidase units obtained without ligand (or extract) addition, at a given ligand concentration [L], and at a saturating ligand concentration, respectively. Kd represents the dissociation constant of the ligand-hormone complex; its value coincides with $\mathrm{EC}_{50}$, the ligand concentration giving $50 \%$ of the maximal response. For serial dilutions of samples, plotting dilution factors versus relative response followed an inverse sigmoidal function, in which the apparent $\mathrm{EC}_{50}$ correspond to the dilution (actual or theoretical) giving 50\% the response for $10 \mathrm{nM}$ estradiol. Apparent $\mathrm{EC}_{50}$ values for each sample (a minimum of two replicas with at least four points each) were calculated using standard non-linear regression methods.

These values were converted to EEQ by assuming they correspond to the $\mathrm{EC}_{50}$ of estradiol (Garcia-Reyero et al., 2001, 2004; Noguerol et al., 2006), $7.29 \times 10^{-9} \mathrm{~g} / \mathrm{mL}$ in our assay (Resende et al., 2013; Boldrin et al., 2013). Six independent experiments were done with the samples, all of them in triplicate.

\section{Results}

\subsection{Mutagenic activity}

Table 1 shows the mean number of revertants/plate, the standard deviation (SD) and the mutagenicity ratio (MR) after treatment with five concentrations of hydroalcoholic extracts of leaves, stalks and roots of A. brachypoda observed in S. typhimurium strains TA98, TA100, TA97a and TA102 in the presence $(+$ S9) and absence (-S9) of metabolic activation.

In the absence of the external metabolizing system, S9 mix, in strain TA98, all the crude extracts induced an increase statistically significant in the number of revertant colonies relative to the negative control, indicating the direct mutagenic activity for this strain.

The extract of leaves of A. brachypoda shows a dose-dependent induction of revertants, with a mutagenic index higher than 2.0 from the concentration of $12 \mathrm{mg} /$ plate. Its mutagenicity in the presence of metabolic activation was observed only at the last concentration evaluated ( $24 \mathrm{mg} /$ plate). The mutagenic effect of the extracts of stalks and roots of A. brachypoda also was positive in the concentration of $24 \mathrm{mg} /$ plate in the experiments without S9 fraction in the TA98 strain. In the presence of S9 mix, only signs of mutagenicity were induced in this strain and in the TA97a for both extracts. In the TA100 and TA102 strains, no mutagenicity was detected in the absence and presence of metabolic activation.

As the extracts showed mutagenic activity using the TA98 strain, the Ames test was applied to the aqueous and dichloromethane fractions in the same conditions for this strain. 
Table 1

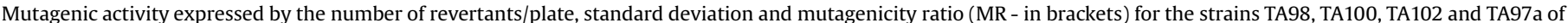

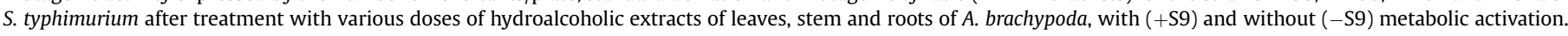

\begin{tabular}{|c|c|c|c|c|c|c|c|c|c|}
\hline \multicolumn{10}{|c|}{ Number of revertants $(\mathrm{M} \pm \mathrm{SD}) /$ plate and $\mathrm{MR}$} \\
\hline \multicolumn{10}{|c|}{ Extract of leaves of $A$. brachyphoda } \\
\hline \multirow{2}{*}{$\frac{\text { Treatments }}{\text { mg/plate }}$} & \multicolumn{2}{|l|}{ TA 98} & \multirow{2}{*}{$\frac{\text { Treatments }}{\text { mg/plate }}$} & \multicolumn{2}{|l|}{$\underline{\text { TA } 100}$} & \multicolumn{2}{|l|}{ TA 102} & \multicolumn{2}{|l|}{ TA 97a } \\
\hline & - S9 & + S9 & & - S9 & + S9 & $-\mathrm{S9}$ & + S9 & - S9 & + S9 \\
\hline $\begin{array}{l}\text { DMSO }^{\mathrm{a}} \\
3 \\
6 \\
12 \\
18 \\
24 \\
\mathrm{C}+\end{array}$ & $\begin{array}{l}27 \pm 3 \\
31 \pm 3(1.1) \\
43 \pm 3(1.6)^{*} \\
59 \pm 6(2.2)^{* *} \\
64 \pm 2(2.4)^{* *} \\
81 \pm 4(3.0)^{* *} \\
935 \pm 44^{\mathrm{a}}\end{array}$ & $\begin{array}{l}33 \pm 1 \\
57 \pm 4(1.7)^{*} \\
52 \pm 3(1.6)^{*} \\
59 \pm 8(1.8)^{*} \\
63 \pm 6(1.9)^{*} \\
69 \pm 6(2.1)^{* *} \\
1395 \pm 76^{\mathrm{d}}\end{array}$ & $\begin{array}{l}\text { DMSO } \\
1.5 \\
3 \\
6 \\
9 \\
12 \\
C+\end{array}$ & $\begin{array}{l}201 \pm 3 \\
223 \pm 11(1.1) \\
230 \pm 14(1.1) \\
252 \pm 29(1.3) \\
257 \pm 22(1.3) \\
258 \pm 13(1.3) \\
1626 \pm 92 b\end{array}$ & $\begin{array}{l}97 \pm 5 \\
116 \pm 8(1.2) \\
92 \pm 3(0.9) \\
93 \pm 2(1.0) \\
101 \pm 2(1.0) \\
100 \pm 5(1.0) \\
1300 \pm 62^{\mathrm{d}}\end{array}$ & $\begin{array}{l}384 \pm 16 \\
287 \pm 24(0.7) \\
332 \pm 34(0.9) \\
412 \pm 25(1.1) \\
368 \pm 31(1.0) \\
403 \pm 27(1.0) \\
1404 \pm 42^{c}\end{array}$ & $\begin{array}{l}445 \pm 11 \\
411 \pm 43(0.9) \\
444 \pm 28(1.0) \\
394 \pm 35(0.9) \\
446 \pm 17(1.0) \\
454 \pm 28(1.0) \\
1208 \pm 72 \mathrm{e}\end{array}$ & $\begin{array}{l}104 \pm 12 \\
90 \pm 10(0.9) \\
94 \pm 8(0.9) \\
98 \pm 25(0.9) \\
83 \pm 10(0.8) \\
93 \pm 13(0.9) \\
1003 \pm 36^{\mathrm{a}}\end{array}$ & $\begin{array}{l}137 \pm 7 \\
188 \pm 8(1.4) \\
163 \pm 5(1.2) \\
192 \pm 8(1.4) \\
129 \pm 9(0.9) \\
123 \pm 6(0.9) \\
1004 \pm 29^{\mathrm{d}}\end{array}$ \\
\hline \multicolumn{10}{|c|}{ Extract of stalk of A. brachyphoda } \\
\hline $\begin{array}{l}\text { DMSO } \\
3 \\
6 \\
12 \\
18 \\
24 \\
C+ \\
\end{array}$ & $\begin{array}{l}27 \pm 3 \\
36 \pm 3(1.3) \\
41 \pm 1(1.5) \\
40 \pm 3(1.5) \\
45 \pm 5(1.7)^{*} \\
55 \pm 5(2.0)^{* *} \\
935 \pm 44^{a} \\
\end{array}$ & $\begin{array}{l}33 \pm 1 \\
55 \pm 2(1.7)^{*} \\
60 \pm 7(1.8)^{*} \\
49 \pm 3(1.5) \\
56 \pm 4(1.7)^{*} \\
59 \pm 4(1.8)^{*} \\
1395 \pm 76^{\mathrm{d}}\end{array}$ & $\begin{array}{l}\text { DMSO } \\
1.5 \\
3 \\
6 \\
9 \\
12 \\
C+ \\
\end{array}$ & $\begin{array}{l}201 \pm 3 \\
210 \pm 17(1.0) \\
246 \pm 21(1.2) \\
233 \pm 16(1.2) \\
234 \pm 11(1.2) \\
252 \pm 19(1.3) \\
1626 \pm 92 b \\
\end{array}$ & $\begin{array}{l}97 \pm 5 \\
108 \pm 15(1.1) \\
83 \pm 17(0.9) \\
117 \pm 14(1.2) \\
139 \pm 10(1.4) \\
121 \pm 19(1.2) \\
1300 \pm 62^{\mathrm{d}} \\
\end{array}$ & $\begin{array}{l}384 \pm 16 \\
444 \pm 42(1.2) \\
436 \pm 31(1.1) \\
480 \pm 17(1.1) \\
499 \pm 38(1.3) \\
322 \pm 21(0.8) \\
1404 \pm 42^{c} \\
\end{array}$ & $\begin{array}{l}445 \pm 11 \\
436 \pm 26(1.0) \\
384 \pm 12(0.9) \\
405 \pm 37(0.9) \\
449 \pm 35(1.0) \\
445 \pm 25(1.0) \\
1208 \pm 72^{\mathrm{e}} \\
\end{array}$ & $\begin{array}{l}104 \pm 12 \\
132 \pm 21(1.3) \\
126 \pm 7(1.2) \\
121 \pm 2(1.2) \\
96 \pm 3(0.9) \\
102 \pm 4(1.0) \\
1003 \pm 36^{\mathrm{a}} \\
\end{array}$ & $\begin{array}{l}137 \pm 7 \\
248 \pm 8(1.8)^{*} \\
259 \pm 9(1.9)^{*} \\
233 \pm 1(1.7)^{*} \\
215 \pm 6(1.6) \\
192 \pm 8(1.4) \\
1004 \pm 29^{\mathrm{d}} \\
\end{array}$ \\
\hline \multicolumn{10}{|c|}{ Extract of roots of $A$. brachyphoda } \\
\hline $\begin{array}{l}\text { DMSO } \\
3 \\
6 \\
12 \\
18 \\
24 \\
C+\end{array}$ & $\begin{array}{l}27 \pm 3 \\
33 \pm 5(1.2) \\
40 \pm 1(1.5) \\
33 \pm 4(1.2) \\
39 \pm 3(1.4) \\
55 \pm 1(2.0)^{* *} \\
935 \pm 44^{\mathrm{a}}\end{array}$ & $\begin{array}{l}33 \pm 1 \\
64 \pm 9(1.9)^{*} \\
45 \pm 3(1.3) \\
40 \pm 1(1.2) \\
52 \pm 2(1.6)^{*} \\
49 \pm 1(1.5) \\
1395 \pm 76^{\mathrm{d}}\end{array}$ & $\begin{array}{l}\text { DMSO } \\
1.5 \\
3 \\
6 \\
9 \\
12 \\
C+\end{array}$ & $\begin{array}{l}201 \pm 3 \\
236 \pm 12(1.2) \\
224 \pm 22(1.1) \\
231 \pm 15(1.1) \\
223 \pm 25(1.1) \\
239 \pm 18(1.2) \\
1626 \pm 92 b\end{array}$ & $\begin{array}{l}97 \pm 5 \\
121 \pm 17(1.2) \\
128 \pm 11(1.3) \\
115 \pm 15(1.2) \\
122 \pm 25(1.3) \\
118 \pm 14(1.2) \\
1300 \pm 62^{\mathrm{d}}\end{array}$ & $\begin{array}{l}384 \pm 16 \\
291 \pm 19(0.8) \\
307 \pm 29(0.8) \\
416 \pm 36(1.0) \\
347 \pm 16(0.9) \\
387 \pm 11(1.0) \\
1404 \pm 42^{\mathrm{c}}\end{array}$ & $\begin{array}{l}445 \pm 11 \\
457 \pm 28(1.0) \\
406 \pm 38(0.9) \\
402 \pm 29(0.9) \\
443 \pm 38(1.0) \\
413 \pm 13(0.9) \\
1208 \pm 72^{\mathrm{e}}\end{array}$ & $\begin{array}{l}104 \pm 12 \\
105 \pm 16(1.0) \\
108 \pm 25(1.0) \\
119 \pm 21(1.1) \\
110 \pm 4(1.1) \\
112 \pm 11(1.1) \\
1003 \pm 36^{\mathrm{a}}\end{array}$ & $\begin{array}{l}137 \pm 7 \\
246 \pm 15(1.8)^{*} \\
215 \pm 8(1.6) \\
188 \pm 2(1.4) \\
170 \pm 8(1.2) \\
159 \pm 9(1.2) \\
1004 \pm 29^{\mathrm{d}}\end{array}$ \\
\hline
\end{tabular}

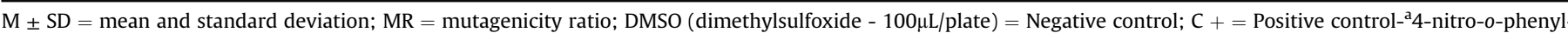

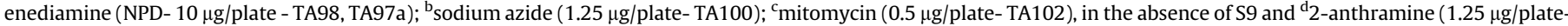
TA98, TA 100 e TA97a); ${ }^{\text {e}} 2$-aminofluorene $(10 \mu \mathrm{g} /$ plate - TA102), in the presence of S9.

The results showed that only aqueous fraction of leaves of A. brachypoda was mutagenic, because induced an increase in the number of revertants relative to the negative control, in the absence of S9, in the strain TA98, with a mutagenic index higher than 2.0 at $22.5 \mathrm{mg} /$ plate (Table 2). As shown in Table 2, signs of mutagenicity were observed for the dichloromethane fractions of leaves and roots of A. brachypoda, at all concentrations tested for TA98 strain, in experiments with the S9-mix.

\subsection{Estrogenic activity}

All extracts, fractions, as well as the isolated compounds brachydin A, brachydin B and brachydin C were analyzed by the RYA assay. Among them, only hydroalcoholic extracts of leaves and roots of A. brachypoda showed significant estrogenic activity, with $E R \alpha$-dependent transcriptional activation activity, showing $\mathrm{EC}_{50}$ of $56.2 \mathrm{~g} / \mathrm{mL}$ and $7.4 \pm 2.3 \mathrm{nM}$ EEQ for extract of leaves and $\mathrm{EC}_{50}$ of $191.3 \mathrm{~g} / \mathrm{mL}$ and $2.16 \pm 0.9 \mathrm{nM}$ EEQ for extract of roots (Table 3 ). The other samples showed no detectable levels of estrogenicity. The variation on $\beta$-galactosidase activity at different extracts concentrations (tested in sextuplicate) are represented in Figs. 2 and 3.

\section{Discussion}

This is the first published assessment on the mutagenic and estrogenic potential of the species $A$. brachypoda. In many cases, people do not realize that treatments based on medicinal plants can cause serious risks to their health (Resende et al., 2015). Thus, given the widespread consumption of $A$. brachypoda by the population, it is essential to perform assays to assess their mutagenicity and other health risks.
In the present study, we investigated the mutagenic effect of the crude ethanolic extracts of leaves, stalk and root of $A$. brachypoda and their aqueous and dichloromethane fractions by Ames test. The bacterial reverse mutation test is commonly employed as an initial screen for genotoxic activity and, in particular, for point mutationinducing activity (OECD, 1997).

All extracts were directly mutagenic on the strain TA98 (Tables 1 and 2), highlighting the ethanolic extract of leaves of $A$. brachypoda, in a dose-dependent manner, with mutagenic index of 3.0 at the highest concentration. Its mutagenicity was also evidenced in strain TA98 in the presence of metabolic activation. After fractionation of the crude extracts, mutagenic activity was found only in the aqueous fraction of leaves $A$. brachypoda, also indicating the direct mutagenicity for TA98 strain. In other strains, only signs of mutagenicity were detected. According to the strain involved, A. brachypoda has direct mutagens acting, at a higher rate, inducing frameshift mutations. The crude extract is more active than the fraction, suggesting a synergic effect.

In relation to the study of the estrogenic potential, in the RYA (Recombinant Yeast Assay) is utilized a recombinant yeast as an experimental model and the transcription of a reporter gene depends on the presence in the midst of compounds capable of binding to the estrogen receptor (Boldrin et al., 2013). According to the results obtained, only hydroalcoholic extracts of leaves and roots of A. brachypoda showed estrogenic activity mediated by ER $\alpha$ dependent transactivation, with $7.4 \pm 2.3$ and $2.16 \pm 0.9 \mathrm{nM}$ EEQ respectively (Table 3 ). The others showed no detectable levels of estrogenicity in the conditions used.

The extracts are mainly composed by a series of unusual dimeric glycosylated flavonoids as well as their aglycones. These unique phenolic compounds from $A$. brachypoda are most probably 
Table 2

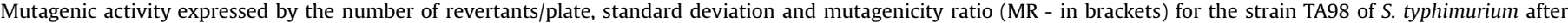
treatment with various doses of aqueous and dichloromethane fractions of the leaves and roots of $A$. brachypoda, with (+S9) and without ( - S9) metabolic activation.

\begin{tabular}{|c|c|c|c|c|c|c|c|}
\hline \multicolumn{8}{|c|}{ Number of revertants $(M \pm S D) /$ plate and $M R$} \\
\hline \multicolumn{4}{|c|}{ Aqueous fraction of leaves of $A$. brachyphoda } & \multicolumn{4}{|c|}{ Dichloromethane fraction of leaves of $A$. brachyphoda } \\
\hline Treatments & TA $98-$ S9 & Treatments & $\mathrm{TA} 98+\mathrm{S} 9$ & Treatments & TA $98-$ S9 & Treatments & TA $98+$ S9 \\
\hline $\mathrm{mg} /$ plate & & $\mathrm{mg} /$ plate & & mg/plate & & mg/plate & \\
\hline DMSO & $16 \pm 2$ & DMSO & $29 \pm 4$ & DMSO & $16 \pm 2$ & DMSO & $17 \pm 2$ \\
\hline 3.7 & $19 \pm 5(1.2)$ & 3.7 & $28 \pm 5(0.9)$ & 0.3 & $19 \pm 4(1.2)$ & 0.05 & $26 \pm 3(1.5)^{*}$ \\
\hline 7.5 & $26 \pm 3(1.7)^{*}$ & 7.5 & $33 \pm 8(1.1)$ & 0.6 & $22 \pm 6(1.4)$ & 0.10 & $27 \pm 5(1.6)^{*}$ \\
\hline 15.0 & $28 \pm 4(1.8)^{*}$ & 15.0 & $38 \pm 4(1.3)$ & 1.2 & $19 \pm 3(1.2)$ & 0.21 & $29 \pm 3(1.7)^{*}$ \\
\hline 22.5 & $32 \pm 6(2.1)^{* *}$ & 22.5 & $42 \pm 7(1.4)$ & 1.8 & $21 \pm 3(1.3)$ & 0.31 & $30 \pm 1(1.8)^{*}$ \\
\hline $\mathrm{C}+$ & $1353 \pm 129^{a}$ & $\mathrm{C}+$ & $639 \pm 47^{\mathrm{b}}$ & $\mathrm{C}+$ & $1353 \pm 129^{a}$ & $\mathrm{C}+$ & $627 \pm 41^{\mathrm{b}}$ \\
\hline \multicolumn{4}{|c|}{ Aqueous fraction of roots of $A$. brachyphoda } & \multicolumn{4}{|c|}{ Dichloromethane fraction of roots of $A$. brachyphoda } \\
\hline Treatments & TA 98 - S9 & Treatments & TA $98+$ S9 & Treatments & TA 98 - S9 & Treatments & TA $98+$ S9 \\
\hline $\mathrm{mg} /$ plate & & $\mathrm{mg} /$ plate & & $\mathrm{mg} /$ plate & & $\mathrm{mg} /$ plate & \\
\hline DMSO & $18 \pm 1$ & DMSO & $17 \pm 2$ & DMSO & $16 \pm 2$ & DMSO & $17 \pm 2$ \\
\hline 1.8 & $22 \pm 4(1.2)$ & 0.16 & $24 \pm 3(1.4)$ & 0.3 & $19 \pm 3(1.2)$ & 0.05 & $24 \pm 1(1.5)^{*}$ \\
\hline 3.7 & $20 \pm 2(1.1)$ & 0.31 & $24 \pm 3(1.4)$ & 0.6 & $22 \pm 6(1.4)$ & 0.10 & $28 \pm 1(1.7)^{*}$ \\
\hline 7.5 & $23 \pm 8(1.3)$ & 0.62 & $22 \pm 1(1.3)$ & 1.2 & $19 \pm 3(1.2)$ & 0.21 & $28 \pm 2(1.7)^{*}$ \\
\hline 11.2 & $24 \pm 8(1.3)$ & 0.94 & $23 \pm 3(1.4)$ & 1.8 & $21 \pm 2(1.3)$ & 0.31 & $27 \pm 1(1.6)^{*}$ \\
\hline $\mathrm{C}+$ & $1163 \pm 184^{\mathrm{a}}$ & $\mathrm{C}+$ & $627 \pm 41^{\mathrm{b}}$ & $\mathrm{C}+$ & $1353 \pm 129^{a}$ & $\mathrm{C}+$ & $627 \pm 41^{\mathrm{b}}$ \\
\hline
\end{tabular}

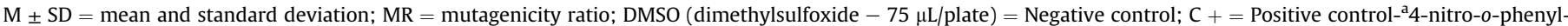
enediamine (NPD- $10 \mu \mathrm{g} /$ plate), in the absence of S9 and ${ }^{\mathrm{b}} 2$-anthramine $(1.25 \mu \mathrm{g} /$ plate), in the presence of S9.

Table 3

Estrogenic activity expressed through the values of estradiol equivalents (EEQ) \pm standard deviation and $\mathrm{EC}_{50}$ values of the ethanolic extracts of leaves and roots of A. brachypoda using a genetically modified strain of S. cerevisae BY4741.

\begin{tabular}{lll}
\hline Samples & $\mathrm{EEQ}(\mathrm{nM})^{\mathrm{a}} \mathrm{M} \pm \mathrm{SD}$ & $\mathrm{EC}_{50}(\mathrm{~g} / \mathrm{mL})^{\mathrm{b}}$ \\
\hline extract of leaves & $7.4 \pm 2.3$ & 56.2 \\
extract of roots & $2.16 \pm 0.9$ & 191.3 \\
$17-\beta$-estradiol & - & $7.29 \times 10^{-9}$ \\
\hline
\end{tabular}

$\mathrm{M} \pm \mathrm{SD}$, Mean and standard deviation.

a EEQ (estradiol equivalents) = concentration of estradiol that elicit the same response as the sample in the RYA assay.

${ }^{b} \mathrm{EC}_{50}=$ the ligand concentration giving $50 \%$ of the maximal response.

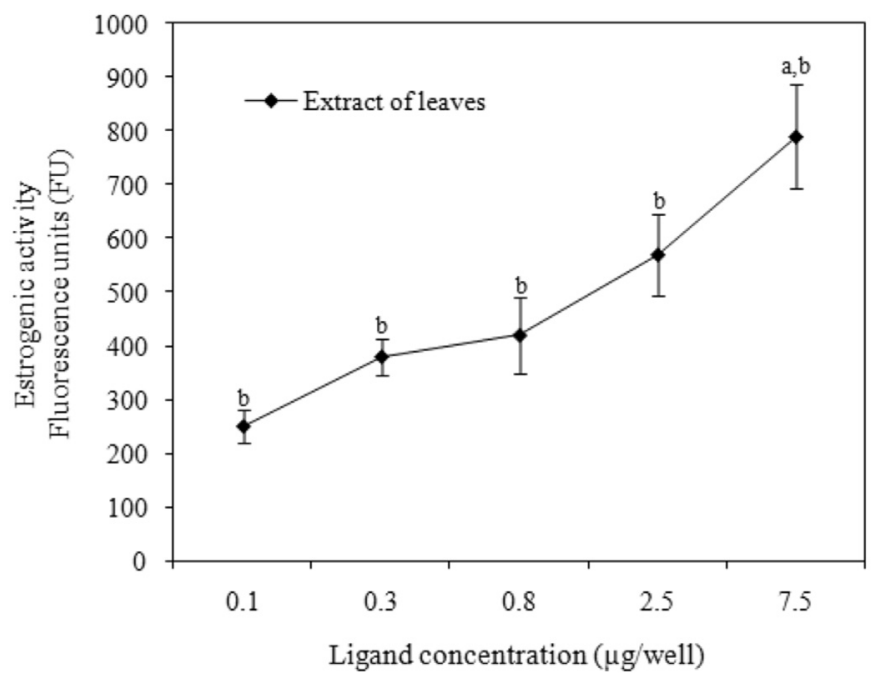

Fig. 2. Estrogenic response for hydroalcoholic extract of leaves of $A$. brachypoda in the recombinant yeast assay. Different concentrations of extract were added to genetically engineered, estrogen-responsive yeast cells and incubated for $6 \mathrm{~h}$. The $\beta$-galactosidase activities were calculated as fluorescence units (FU). Values are averages of six independent experiments; bars indicate value ranges. a Significantly different from the negative control, DMSO, FU $=220 \pm 19$. ' Significantly different from the positive control, $17-\beta$-estradiol, FU $=5910 \pm 224$ (one-way ANOVA, Tukey test; $\mathrm{p}=0.05$ ). implicated in the mutagenic and estrogenic potential observed in this study. The first phytochemical studies reports showed the presence of flavonoids luteolin and apigenin (Blatt et al., 1998). Alcerito et al. (2002) have isolated four flavonoids from waxes of the leaves of $A$. brachypoda: cirsimaritin, hispidulin, cirsiliol (first report in the family) and $3^{\prime}, 4^{\prime}$-dihydroxy-5,6,7-trimethoxyflavone (first reported as a product natural). There are also reports of the presence of saponins, cardiac glycosides, phenolic compounds, tannins, steroids, pentacyclic triterpenes, betulinic acid, ursolic acid and oleanolic acid and three new compounds: brachydin A, brachydin B and brachydin C in the extract of the roots (Rocha et al., 2011, 2014). Recently, Rocha et al. (2017) isolated of two previously undescribed phenylethanoid glycosides derivatives and

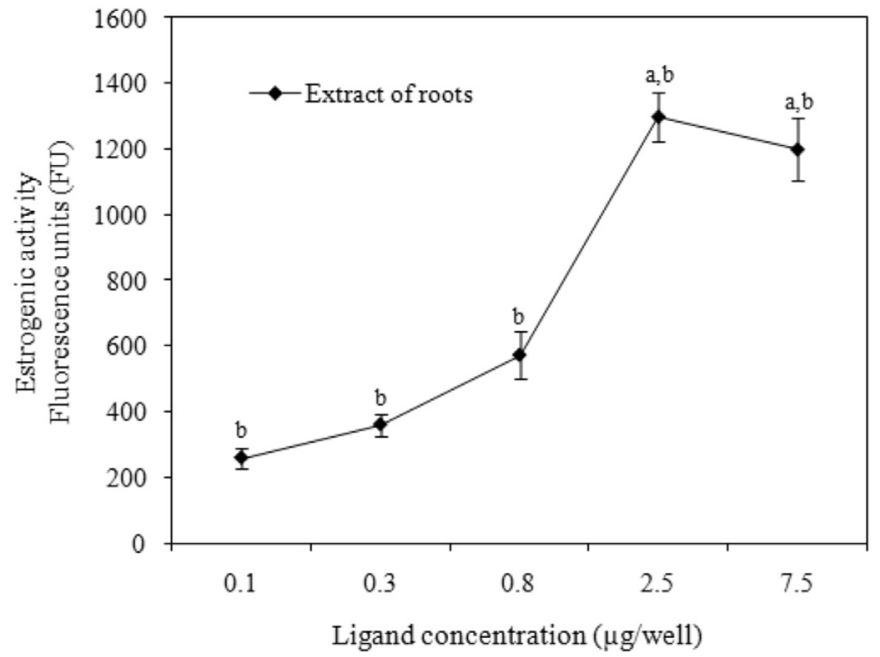

Fig. 3. Estrogenic response for hydroalcoholic extract of roots of A. brachypoda in the recombinant yeast assay. Different concentrations of extract were added to genetically engineered, estrogen-responsive yeast cells and incubated for $6 \mathrm{~h}$. The $\beta$-galactosidase activities were calculated as fluorescence units (FU). Values are averages of six independent experiments; bars indicate value ranges. a'Significantly different from the negative control, DMSO, FU $=282 \pm 31$. ' Significantly different from the positive control, 17 - $\beta$-estradiol, $\mathrm{FU}=7910 \pm 453$ (one-way ANOVA, Tukey test; $\mathrm{p}=0.05$ ). 
seven unusual glycosylated dimeric flavonoids.

The health benefits of flavonoids are well known and are displayed as a remarkable range of biochemical and pharmacological properties that may significantly affect the function of various mammalian cells (Snijman et al., 2007). However, it is necessary to clarify the mechanisms and the conditions that mediate the biological effects before considering them as therapeutical agents (Duarte Silva et al., 2000). According to Kay (2010), there are insufficient data to provide conclusive evidence on the health effects of most flavonoid subclasses. Given the fact that flavonoids are considered as antioxidant agents it could seem unclear why the genotoxicity of some flavonoids could be explained by a pro-oxidant action. The mechanisms underlying this genotoxic activity depend on the structure of the flavonoid and it seems that they are either dependent on the biotransformation of the compound or on the production of reactive oxygen species (Duarte Silva et al., 2000).

According to the literature, the fundamental characteristics for the presence of mutagenic activity in the flavonoid structure are: a free hydroxyl at the 3 position of the ring $C$, double bond between the 2 and 3 positions and the keto group at the 4 position (Rietjens et al., 2005; Resende et al., 2012). Some of these structural features are exhibited by isolated four flavonoids by Alcerito et al. (2002) of the leaves of $A$. brachypoda, which explains the greater mutagenic activity observed in the aerial parts of this plant species. Duarte Silva et al. (2000) clarify that the mechanisms underlying mutagenicity of the flavonoids in S. typhymurium TA98 may involve the ability of the B ring to oxidize to a quininoid intermediate followed by the tautomerisation of the proton of the 3-hydroxyl group to 3 keto compounds. The quinone methide metabolites are capable of covalently binding to DNA and act as alkylating DNA-reactive intermediates. Complementing, Snijman et al. (2007) showed that apart from the increased polarity, changes in the mutagenic behaviour due to the glycosylation of the flavonoid could also be attributed to steric hindrance of the bulky sugar moieties. Therefore, the presence of glycosylated flavonoids may have influence on the genotoxicity of the extracts of stalk and root of $A$. brachypoda, neutralizing the mutagenic effect.

In addition to mutagenicity, another important class of toxicity arising from the environment is endocrine disruption (Resende et al., 2013). According to Ward and Kuhnle (2010), phytoestrogens are a group of non-steroidal polyphenolic plant metabolites that induce biological responses and can mimic or modulate the action of endogenous oestrogens, often by binding to oestrogen receptors. Interest in plant-derived estrogens (or phytoestrogens) has recently been increased by the realization that hormone replacement therapy is not as safe or effective as previously thought (Innocenti et al., 2007). Estrogens may act by stimulating cell transformation and cell proliferation, and it may act as a tumor initiator through its metabolites by inducing damage to cellular macromolecules such as DNA (Van Duursen et al., 2004).

Phytochemicals have been shown to possess antioxidant, anticancer, and antiviral properties. Because of these properties, they are generally regarded as safe (Van Duursen et al., 2004). However, in the present study, the results are extremely worrying; the obtained data showed that compounds with estrogenic activity present in the extracts have the potential to induce DNA damage.

The use of the recombinant yeast system for screening purposes presents several advantages including the lack of known endogenous receptors, use of media that is devoid of steroids, and its weak biotransformation activity. In the system used in this study, the estrogenic activity of the extracts results from its direct interaction with the estrogen receptor (ER) (Zacharewski, 1998). The yeast is transfected with an expression vector encoding an ER and a reporter gene vector composed of an estrogen-sensitive promoter. Reporter gene assays using recombinant yeast cells is a rapid screening alternative to live animal or cell cultures studies (Passos et al., 2009).

Two characteristics of the yeast cell contribute to the success of the RYA. First, yeast has no endogenous system homologous to vertebrate nuclear receptors that could interfere with the assay. Second, the folding and post translational processing of vertebrate protein in yeast is very similar to the one from mammalian cells, which results in the preservation of the native receptor structure when expressed in yeast. This is of paramount interest, since the correct structure of the ligand-binding domain of the receptor determines the specificity of the system, that is, its capability to distinguish between ligands and non-ligands (Noguerol et al., 2006).

The flavonoids have some structural similarities to the natural estrogen estradiol, as well as other steroid hormones and steroid hormone antagonists (Zand et al., 2000), being able to interact with the estrogen receptor and induce gene expression similar to estrogens, albeit at a lower affinity (Ferguson, 2001).

According to Ward and Kuhnle (2010), an aromatic ring and a hydroxyl group are important features for a compound to bind to the receptor. For Fang et al. (2001), some distinguishing features were found to be essential for xenoestrogen activity, using 17-bestradiol as a template: (1) $\mathrm{H}$ bonding capacity of the phenolic ring, mimicking the 3-OH, (2) $\mathrm{H}$ bond donor mimicking the17-b-OH, (3) O-O distance between 3- and 17-b-OH, and its orientation, (4) hydrophobicity and (5) a ring structure. Zand et al. (2000) reports that hydroxyl groups at position $4^{\prime}$ confer more potent estrogenic activity and the most potent estrogenic compounds have between 2 and 4 hydroxyl groups. At least one is bonded at position 7 of the Aring, and another at position 4' of the B-ring.

Several compounds present in the extracts present some of these structural characteristics, with emphasis on apigenin. Innocenti et al. (2007) suggest that apigenin can stimulate ERsdependent biological pathways, although with a smaller potency as compared with the endogenous hormone. Both receptors, $\alpha$ and $\beta$, can be activated by apigenin. However, considering that the extract is a complex mixture of several known and yet unknown organic compounds, the observed estrogenic activity may be due to the interaction between them.

It is, however, well established that phytoestrogens belong to different classes of compounds; therefore, chemical structures alone are not sufficient to predict estrogenic activity (Resende et al., 2013).

\section{Conclusions}

Considering the popular use of $A$. brachypoda, these results contribute to valuable data suggesting caution in their use. Further research is needed to reach a better understanding of the interactions involved in ligand-receptor binding and their mutagenic potential to guarantee their safer and more effective application to human health. Selective estrogen receptor modulators (SERMs) have been developed to preserve the benefits of traditional hormone therapy while avoiding unwanted side effects. Phytoestrogens may be added to the list of SERMs, given their agonist/ antagonist properties at estrogen sensitive tissues (Oliveira et al., 2013). However, the obtained results in this study showed the presence of compounds capable of interacting with the ER, as observed in RYA and induce damage in the genetic material by the Ames test. Thus, when we deal with the adverse effects related to environmental estrogens, we have to pay attention to plant-derived phytoestrogens (Han et al., 2002).

\section{Acknowledgements}

The authors are grateful for grant 09/52237-9, Fundação de Amparo à Pesquisa do Estado de São Paulo (FAPESP) for providing 
financial aid to W. Vilegas. The authors also thank Conselho Nacional de Desenvolvimento Científico e Tecnológico (CNPq) and Coordenação de Aperfeiçoamento de Pessoal de Nível Superior (CAPES) for grants to E. A. Varanda and W. Vilegas.

\section{Conflict of interest}

The authors declare no conflicts of interest.

\section{Transparency document}

Transparency document related to this article can be found online at http://dx.doi.org/10.1016/j.yrtph.2017.08.010.

\section{References}

Alcerito, T., Barbo, F.E., Negri, G., Santos, D.Y.A.C., Meda, C.I., Young, M.C.M., Chávez, D., Blatt, C.T.T., 2002. Foliar epicuticular wax of Arrabidaea brachypoda: flavonoids and antifungal activity. Bioch Syst. Ecol. 30, 677-683.

Barbosa, W.L.R., Pinto, L.N., Quignard, E., Vieira, J.M.S., Silva Jr., J.O.C., Albuquerque, S., 2008. Arrabidaea chica (HBK) Verlot: phytochemical approach, antifungal and trypanocidal activities. Rev. Bras. Farmacogn. 18, 544-548.

Bernstein, L., Kaldor, J., Mccann, J., Pike, M.C., 1982. An empirical approach to the statistical analysis of mutagenesis data from the Salmonella test. Mutat. Res. 97, $267-281$.

Blatt, C.T.T., Santos, M.S., Salatino, A., 1998. Flavonoids of Bignoniaceae from the "cerrado" and their possible taxonomic significance. Plant Syst. Evol. 210, 289-292.

Boldrin, P., Resende, F.A., Höhne, A., de Camargo, M., Espanha, L., Nogueira, C., Melo, M., Vilegas, W., Varanda, E., 2013. Estrogenic and mutagenic activities of Crotalaria pallida measured by recombinant yeast assay and Ames test. BMC Complement. Altern. Med. 13, 216.

Brandão, G.C., Kroon, E.G., dos Santos, J.R., Stehmann, J.R., Lombardi, J.A., Braga de Oliveira, A., 2010. Antiviral activity of bignoniaceae species occurring in the state of Minas Gerais (Brazil): part 1. Lett. Appl. Microbiol. 51, 469-476.

Cortez de Sá, J., Almeida-Souza, F., Mondêgo-Oliveira, R., Oliveira Idos, S., Lamarck, L., Magalhães Ide, F., Ataídes-Lima, A.F., Ferreira Hda, S., AbreuSilva, A.L., 2016. Leishmanicidal, cytotoxicity and wound healing potential of Arrabidaea chica Verlot. BMC Complement. Altern. Med. 16, 1.

Duarte Silva, I., Gaspar, J., Gomes Da Costa, G., Rodrigues, A.S., Laires, A., Rueff, J., 2000. Chemical features of flavonols affecting their genotoxicity. Potential implications in their use as therapeutical agents. Chem. Biol. Interact. 124, 29-51.

Van Duursen, M.B., Sanderson, J.T., De Jong, P.C., Kraaij, M., Van Den Berg, M., 2004. Phytochemicals inhibit catechol-O-methyltransferase activity in cytosolic fractions from healthy human mammary tissues: implications for catechol estrogen-induced DNA damage. Toxicol. Sci. 81, 316-324.

Fang, H., Tong, W., Shi, L.M., Blair, R., Perkins, R., Branham, W., Hass, B.S., Xie, Q. Dial, S.L., Moland, C.L., Sheehan, D.M., 2001. Structure-activity relationships fo a large diverse set of natural, synthetic, and environmental estrogens. Chem. Res. Toxicol. 14, 280-294.

Ferguson, L.R., 2001. Role of plant polyphenols in genomic stability. Mutat. Res. 475, 89-111.

Garcia-Reyero, N., Grau, E., Castillo, M., López de Alda, M.J., Barceló, D., Piña, B., 2001 Monitoring of endocrine disruptors in surface waters by the yeast recombinant assay. Environ. Toxicol. Chem. 20,1152-1158.

Garcia-Reyero, N., Requena, V., Petrovic, M., Fischer, B., Hansen, P.D., Díaz, A. Ventura, F., Barceló, D., Piña, B., 2004. Estrogenic potential of halogenated derivatives of nonylphenol ethoxylates and carboxylates. Environ. Toxicol. Chem. 23, 705-711.

Gemelli, T.F., Prado Lda, S., Santos, F.S., de Souza, A.P., Guecheva, T.N., Henriques, J.A. Ferraz Ade, B., Corrêa, D.S., Dihl, R.R., Picada, J.N., 2015. Evaluation of safety of Arrabidaea chica Verlot (Bignoniaceae), a plant with healing properties. J. Toxicol. Environ. Health A 78, 1170-1180.

González, B., Suárez-Roca, H., Bravo, A., Salas-Auvert, R., Avila, D., 2000. Chemica composition and biological activity of extracts from Arrabidaea bilabiata. Pharm. Biol. 38, 287-290.

Green, S., Chambon, P., 1991. The oestrogen receptor: from perception to mechanism. In: PARKER, M.G. (Ed.), Nuclear Hormone Receptors. Academic Press, London, pp. 15-38.

Han, D.H., Denison, M.S., Tachibana, H., Yamada, K., 2002. Relationship between estrogen receptor-binding and estrogenic activities of environmental estrogens and suppression by flavonoids. Biosci. Biotechnol. Biochem. 66, 1479-1487.

Innocenti, G., Vegeto, E., Dall'acqua, S., Ciana, P., Giorgetti, M., Agradi, E., Sozzi, A., Fico, G., Tomè, F., 2007. In vitro estrogenic activity of Achillea millefolium L. Phytomed 14, 147-152.

Kay, C.D., 2010. The future of flavonoid research. Brit J. Nutr. 104, 91-95.

Leite, J.P.V., Oliveira, A.B., Lombardi, J.A., Filho, J.D.S., Chiari, E., 2006. Trypanocidal activity of triterpenes from Arrabidaea triplinervia and derivates. Biol. Pharm. Bull. 29, 2307-2309.
Lima, C.S.A., de Amorim, E.L.C., Fonseca, K.X.R.S., Chiappeta, A.A., Nunes, X.P., Agra, M.F., da Cunha, E.V.L., Silva, M.S., Barbosa-Filho, J.M., 2003. Antimicrobial activity of a mixture of two isomeric phenylpropanoid glycosides from Arrabidaea harleyi A.H. Gentry (Bignoniaceae). Braz J. Pharm. Sci. 39, 77-81.

Mafioleti, L., da Silva Junior, I.F., Colodel, E.M., Flach, A., Martins, D.T., 2013. Evaluation of the toxicity and antimicrobial activity of hydroethanolic extract of Arrabidaea chica (Humb. \& Bonpl.) B. Verl. J. Ethnopharmacol. 150, 576-582.

Maron, D.M., Ames, B.N., 1983. Revised methods for the Salmonella mutagenicity test. Mutat. Res. 113, 173-215.

Michel, A.F., Melo, M.M., Campos, P.P., Oliveira, M.S., Oliveira, F.A., Cassali, G.D., Ferraz, V.P., Cota, B.B., Andrade, S.P., Souza-Fagundes, E.M., 2015. Evaluation of anti-inflammatory, antiangiogenic and antiproliferative activities of Arrabidaea chica crude extracts. J. Ethnopharmacol, 165, 29-38.

Noguerol, T.N., Boronat, S., Jarque, S., Barceló, D., Piña, B., 2006. Detection of hormone receptor ligands in yeast by fluorogenic methods. Talanta 69, 351-358.

OECD Guideline For Testing Of Chemicals, 471, Bacterial Reverse Mutation Test, 1997.

Oliveira, A.P., de Sousa, J.F., da Silva, M.A., Hilário, F., Resende, F.A., de Camargo, M.S., Vilegas, W., dos Santos, L.C., Varanda, E.A., 2013. Estrogenic and chemopreventive activities of xanthones and flavones of Syngonanthus (Eriocaulaceae). Steroids 78, 1053-1063.

Passos, A.L., Pinto, P.I., Power, D.M., Canario, A.V., 2009. A yeast assay based on the gilthead sea bream (teleost fish) estrogen receptor beta for monitoring estrogen mimics. Ecotoxicol. Environ. Saf. 72, 1529-1537.

Pauletti, P.M., Castro-Gamboa, I., Siqueira Silva, D.H., Young, M.C., Tomazela, D.M., Eberlin, M.N., da Silva, Bolzani, V., 2003. New antioxidant C-glucosylxanthones from the stems of Arrabidaea samydoides. J. Nat. Prod. 66, 1384-1387.

Resende, F.A., Vilegas, W., Dos Santos, L.C., Varanda, E.A., 2012. Mutagenicity of flavonoids assayed by bacterial reverse mutation (Ames) test. Molecules 17, 5255-5268.

Resende, F.A., de Oliveira, A.P., de Camargo, M.S., Vilegas, W., Varanda, E.A., 2013. Evaluation of estrogenic potential of flavonoids using a recombinant yeast strain and MCF7/BUS cell proliferation assay. PLoS One 8 (10), e74881.

Resende, F.A Campos, D.L., da Silva, V.C. De Grandis, R.A. Souza, L.P. Leonardo Junior, C.S., da Rocha, C.Q., dos Santos, L.C., Vilegas, W., Varanda, E.A., 2015 Mutagenicity and chemopreventive activities of Astronium species assessed by Ames test. Regul. Toxicol. Pharmacol. 72, 506-513.

Rietjens, I.M.C.M., Boersma, M.G., Van Der Woude, H., Jeurissen, S.M.F., Schutte, M.E., Alink, G.M., 2005. Flavonoids and alkenylbenzenes: mechanisms of mutagenic action and carcinogenic risk. Mutat. Res. 574, 124-138.

Rocha, C.Q. Vilela, F.C., Cavalcante, G.P., Santa-Cecília, F.V., Santos e Silva, L., dos Santos, M.H., Giusti-Paiva, A., 2011. Anti-inflammatory and antinociceptive effects of Arrabidaea brachypoda (DC.) Bureau roots. J. Ethnopharmacol. 133, 396-401.

Rocha, C.Q., Queiroz, E.F., Meira, C.S., Moreira, D.R.M., Soares, M.B.P., Marcourt, L., Vilegas, W., Wolfender, J.L., 2014. Dimeric flavonoids from Arrabidaea brachypoda and assessment of their anti-Trypanosoma cruzi activity. J. Nat. Prod. 77, 1345-1350.

Rocha, C.Q., de-Faria, F.M., Marcourt, L., Ebrahimi, S.N., Kitano, B.T., Ghilardi, A.F., Luiz Ferreira, A., de Almeida, A.C., Dunder, R.J., Souza-Brito, A.R., Hamburger, M., Vilegas, W., Queiroz, E.F., Wolfender, J.L., 2017. Gastroprotective effects of hydroethanolic root extract of Arrabidaea brachypoda: evidences of cytoprotection and isolation of unusual glycosylated polyphenols. Phytochemistry 135, 93-105.

Santos, V.C. Longo, T.B. Garcia, A.L., Richter, M.F. Guecheva, T.N., Henriques, J.A., Ferraz Ade, B., Picada, J.N., 2013. Evaluation of the mutagenicity and genotoxicity of Arrabidaea chica Verlot (Bignoneaceae), an Amazon plant with medicinal properties. J. Toxicol. Environ. Health A 76, 381-390.

Schneider, J.C., Guarente, L., 1991. Vectors for expression of cloned genes in yeast: regulation, overproduction, and underproduction. Meth Enzymol. 194, $373-388$.

Silva, T.B., Costa, C.O., Galvão, A.F., Bomfim, L.M., Rodrigues, A.C., Mota, M.C., Dantas, A.A., Dos Santos, T.R., Soares, M.B., Bezerra, D.P., 2016. Cytotoxic potential of selected medicinal plants in northeast Brazil. BMC Complement. Altern. Med. 16, 199.

Siraichi, J.T., Felipe, D.F., Brambilla, L.Z., Gatto, M.J., Terra, V.A., Cecchini, A.L. Cortez, L.E., Rodrigues-Filho, E., Cortez, D.A., 2013. Antioxidant capacity of the leaf extract obtained from Arrabidaea chica cultivated in Southern Brazil. PLoS One 8 (8), e72733.

Snijman, P.W., Swanevelder, S., Elizabeth Joubert, E., Green, I.R., Gelderblom, W.C.A., 2007. The antimutagenic activity of the major flavonoids of rooibos (Aspalathus linearis): some dose-response effects on mutagen activation-flavonoid interactions. Mutat. Res. 631, 111-123.

Ward, H.A., Kuhnle, G.G., 2010. Phytoestrogen consumption and association with breast, prostate and colorectal cancer in EPIC Norfolk. Arch. Biochem. Biophys. 501, 170-175.

Zacharewski, T., 1998. Identification and assessment of endocrine disruptors: limitations of in vivo and in vitro assays. Environ. Health Perspect. 106, 577-582.

Zand, R.S., Jenkins, D.J., Diamandis, E.P., 2000. Steroid hormone activity of flavonoids and related compounds. Breast Cancer Res. Treat. 62, 35-49.

Zorn, B., García-Piñeres, A.J., Castro, V., Murillo, R., Mora, G., Merfort, I., 2001. 3Desoxyanthocyanidins from Arrabidaea chica. Phytochemistry 56, 831-835. 